REVIJA ZA ELEMENTARNO IZOBRAŽEVANJE

JOURNAL OF ELEMNTARY EDUCATION

Vol. 13, No. 2, pp. 169-192, Junij 2020

\title{
MEDPREDMETNO POVEZOVANJE GIBANJA IN GLASBE V ZGODNJEM OBDOBJU OTROŠTVA
}

Miha MarinšEK ${ }^{1}$, MAnja ŠUmeR ${ }^{2} \&$ Olga DenaC $^{1}$

Potrieno/Accepted

15. 10. 2019

Objavljeno/Published 8. 6.2020

Ključne besede: gibalne spretnosti, ritmični posluh, načelo horizontalne povezanosti, medpredmetno povezovanje gibanja in glasbe, eksperimentalni program

Keywords: movement skills, rhythmic abilities, principle of integration, integration of movement and music experimental programme

UDK/UDC: 373.2:[796.012.265:78]
${ }^{1}$ Univerza v Mariboru, Pedagoška fakulteta, Maribor, Slovenija

${ }^{2}$ Osnovna šola Prežihovega Voranca Maribor, Slovenija

CORRESPONDING AUTHOR/KORESPONDENČNI AVTOR miha.marinsek@um.si

\section{Izvleček/Abstract}

Namen raziskave je bil preučiti učinke eksperimentalnega programa, ki temelji na povezovanju področij gibanja in glasbe, na usvajanje temeljnih gibalnih spretnosti in na razvoj ritmičnega posluha. $V$ raziskavi je sodelovalo 62 otrok, starih od 5 do 6 let. Rezultati so pokazali, da so otroci gibalno-glasbenega in gibalnega programa dosegli večji napredek v temeljnih gibalnih spretnostih in stopnji razvitosti ritmičnega posluha kot otroci kontrolne skupine. $\mathrm{Ob}$ upoštevanju načela horizontalne povezanosti različnih področij dejavnosti in različnih vidikov otrokovega razvoja in učenja se je eksperimentalni gibalnoglasbeni program pokazal kot učinkovitejši.

\section{Integration of Movement and Music in Early Childhood}

The purpose of this study was to examine the influence of an experimental programme based on the integration of movement and music on the development of fundamental movement skills and rhythmic abilities. Sixtytwo children aged from 5 to 6 years participated in the study. Results showed that children who were included in the music and movement programme as well as those included in the movement-only programme improved more in fundamental movement skills and rhythmic abilities than children from the control group. Considering the principle of horizontal integration of different curricular areas and different viewpoints on the child's development and learning, the experimental music and movement programme proved to be more effective. 


\section{Teoretična izhodišča}

Medpredmetno povezovanje je didaktični pristop, v okviru katerega je učenje organizirano tako, da povezuje skupne značilnosti učnih področij v smiselno celoto. Kurikulum za vrtce (1999) v okviru načela horizontalne povezanosti spodbuja medpodročno povezovanje šestih področij (gibanje, jezik, družba, matematika, umetnost in narava), ki poudarja soodvisnost vidikov otrokovega razvoja in s tem upravičenost in uporabnost povezovanja dejavnosti različnih področij. Kurikularne povezave so glede na število vključenih predmetov lahko enopredmetne, če obstajajo znotraj posameznega predmeta, in večpredmetne, če obstajajo med dvema predmetoma, med več ali vsemi predmeti (Pavlič Škerjanc, 2008; Varl in Duh, 2017). Medpredmetno povezovanje lahko temelji na ravni vsebin, ciljev in/ali procesov. Povezovanje, ki temelji samo na učni snovi, »[...] še ne zagotavlja uspešne povezave med predmeti, saj tovrstni pristop ni v skladu s sodobnimi kurikularnimi strategijami, ki bolj kot učno vsebino poudarjajo pomen procesov in ciljev učenja (Sicherl Kafol, 2007, str. 115). V smislu medpredmetnosti lahko torej pri načrtovanju izhajamo iz učnih ciljev različnih ravni zahtevnosti in področij otrokove osebnosti (afektivne, kognitivne, psihomotorične), ki postanejo glavni element povezovanja med različnimi predmetnimi področji. »Prednosti takšnega pristopa so, da učenci pri medpredmetnem reševanju učnih situacij razvijajo interes in motivacijo, dosegajo boljše učne uspehe, izražajo samozavest in so zmožni vzpostavljati transfer učnih znanj in spretnosti med različnimi predmetnimi področji« (Denac, Čagran, Žnidaršič in Sicherl - Kafol, 2013, str. 42).

\section{Temeline gibalne spretnosti}

Temeljne gibalne spretnosti (TGS) predstavljajo osnovne gradnike kasnejših specializiranih gibanj, ki so potrebni za sodelovanje $\mathrm{v}$ različnih športnih dejavnostih v obdobju mladostništva in odraslosti (Gallahue in Ozmun, 2006; Seefeldt, 1980). 
Otroci, ki so bolj vešči v TGS, v večji meri sodelujejo pri športnih aktivnostih v kasnejših obdobjih življenja in izkazujejo boljšo telesno pripravo (Barnett, Van Beurden, Morgan, Brooks in Beard., 2008; Gašparović, Petrić, Štemberger, Rakovac, in Blažević, 2017; Hardy, King, Farrell, Macniven in Howlett, 2009; Jaakkola, Yli Piipari, Huotari, Watt in Liukkonen, 2016; Morrow idr., 2013) kot manj vešči otroci. Neustrezno pridobljene TGS pomenijo pomanjkanje gibalnih kompetenc, to pa praviloma vodi $\mathrm{v}$ neprimerno in neredno telesno in/ali športno dejavnost $\mathrm{v}$ odraslosti (Pišot, 2012). Prav zaradi tega je pomembno, da otroke pričnemo seznanjati s TGS že v zgodnjem otroštvu.

TGS delimo na stabilnostne spretnosti (stoja na eni nogi, vrtenje ipd.), lokomotorne spretnosti (tek, skoki ipd.) in manipulativne spretnosti (prijemi, meti žoge ipd.). Vsaka TGS je sestavljena iz preprostih gibalnih akcij, ki si sledijo v časovnem zaporedju in ustvarjajo edinstven gibalni vzorec vsake spretnosti. Za otrokov razvoj je pomembno, da usvoji časovno usklajen gibalni vzorec, saj to pogojuje njegovo pravilno izvedbo in s tem uporabnost takšne gibalne spretnosti. Strokovnjaki ugotavljajo, da otroci v današnjem času zamujajo v usvajanju TGS ali jih sploh ne usvojijo (Beurden, Zask, Barnett in Dietrich, 2002; Stratton idr., 2009; Lemos, Avigo in Barela; 2012; Stodden idr., 2008). Za usvajanje TGS je pomembno, da vzgojitelj, učitelj ali športni pedagog pri učenju usmerjajo otroke, saj jih lahko s tem učinkovito vodijo $\mathrm{k}$ pravilni izvedbi ali jim pomagajo nadoknaditi morebitne primanjkljaje (Goodway, Robinson in Crowe, 2013; Petrić, Kostadin in Peić, 2018). Otroci se namreč TGS ne naučijo sami od sebe, ampak jih $\mathrm{k}$ temu morajo voditi odrasli (Clarke, 2007) tako, da jim omogočajo izvajanje TGS in zagotavljajo njihovemu razvoju primerno učno okolje, $v$ katerem mora prevladovati gibalno-didaktična igra kot osnovna učna metoda (Zoglowek in Aleksandrovich, 2016).

\section{Elementarne glasbene sposobnosti - ritmični posluh}

Časovni potek glasbenega dogajanja določajo: ritem, metrum in tempo. Ritem je zaporedno ponavljanje dveh ali več zvočnih elementov, ki prinaša urejenost, metrum je izmenjava poudarjenih z nepoudarjenimi zvočnimi elementi ritmičnega gibanja, tempo pa je določena hitrost izvajanja osnovne ritmične enote ali glasbenega dela.

Ritmični posluh, poleg melodičnega posluha, spada med elementarne glasbene sposobnosti. Sloboda (1986) meni, da ritmičnega vedenja ne zasledimo pred prvim 
letom starosti. Da lahko neko vedenje opredelimo kot ritmično, se mora pojaviti eno od naslednjih vedenj: podelitev dobe, imitacija danega ritmičnega vzorca, ritmično gibanje ali udarjanje ob glasbi, izpustitev dobe, pri čemer se po pavzi otroci zopet pravilno vključijo $\mathrm{v}$ ritmični tok. $\mathrm{V}$ drugem letu starosti se povečata število in kakovost reakcij na glasbo. Boljša je tudi koordinacija gibov ob glasbi. Moog (1968) je ugotovil, de se je desetina otrok med 18. in 24. mesecem sposobna krajši čas ritmično gibati ob glasbi. Velik preskok v razvoju ritmičnega posluha lahko opazimo po petem letu starosti (Božič, Habe in Jerman, 2007), kjer je viden napredek na področju ohranjanja ritma, tako $\mathrm{v}$ hoji kot $\mathrm{v}$ ploskanju. Med ritmične sposobnosti uvrščamo: zaznavanje osnovnega glasbenega utripa, izvajanje podelitve dobe, usklajevanje gibanja $\mathrm{z}$ glasbo ter ohranjanje enakomernega osnovnega glasbenega utripa skozi glasbeno tišino (Borota in Kovačič Divjak, 2015). Ritmični posluh pri otroku razvijamo z različnimi glasbenimi dejavnostmi, kot so izvajanje (petje in igranje), poslušanje in ustvarjanje glasbe; preverjanje razvitosti ritmičnega posluha pa z glasbeno-didaktičnimi igrami, ki nam ponujajo priložnost, da si otrok še intenzivneje razvija določeno glasbeno sposobnost (Denac, 2012a, 2012b).

\section{Povezovanje področij gibanja in glasbe}

Gibanje in glasba sta pri poučevanju v vzajemni odvisnosti. Glasba lahko pomaga otrokom pri učenju gibalnih spretnosti in gibanje lahko pomaga pri razvijanju glasbenih sposobnosti. Ritem in takt lahko opredeljujeta enakomernost ponavljanja delov gibalne spretnosti. Pri učenju TGS je ponavljanje njenih delov, ki ustvarjajo gibalni vzorec, ključnega pomena za pravilno izvedbo, zato je ritem v procesu učenja TGS zelo pomemben. Vključevanje glasbe omogoča poudarjanje posameznih delov spretnosti oziroma spreminjanje izvedbe v celoti (nežni, odrezavi, mehki, težki gibi), kar lahko pomaga otroku pri učenju spretnosti (Pistotnik, 2011; Rajtmajer, 2011). Ob glasbi postane gibanje sproščeno, urejeno in intenzivnejše (Denac, 2012a), hkrati pa gibanje ob ritmični spremljavi spodbudi zavedanje različnih telesnih položajev in s tem izboljša kinestetični občutek (Phillips - Silver in Trainor, 2005).

Številni glasbeni pedagogi, med njimi tudi Emil Jaques Dalcroze in Carl Orff, so zagovarjali gibanje kot enega izmed ključnih korakov v poučevanju glasbe (Sušić, 2017). Z gibom otroci izražajo metrum ter gib uporabijo kot sredstvo za oblikovanje in izražanje zvočnih predstav, zato je koristno, da poučevanje glasbe gradimo na povezovanju gibanja in glasbe. Emil Jaques Dalcroze (1865-1950) velja za pionirja 
poučevanja glasbe s pomočjo gibanja telesa. Znana je njegova misel, da lahko vsako glasbeno idejo izrazimo $\mathrm{z}$ gibanjem telesa in vsako gibanje telesa lahko preoblikujemo v glasbeno gibanje (Dalcroze, 1932). Njegov pristop k poučevanju glasbe obsega ritmično vzgojo oz. ritmiko, solfeggio $z$ vajami za slušno občutljivost za glasbo oz. za študij glasbene teorije in prakse ter improvizacijo. Dalcroze kot ključne elemente za razvoj muzikalnosti vključuje - poleg izražanja logičnih misli (govor) in občutkov (zvok) - tudi telesno izražanje (gesto) (Bachmann, 1995). Osnovni cilj Dalcrozovega didaktičnega pristopa je s pomočjo ritma in telesne dejavnosti ustvariti neposredno pot med telesom, umom in občutki (Thresher, 1964). Med učenjem lahko otroci usklajujejo gibanje ob ritmu, ali poustvarjajo ritem na podlagi gibanja. Podobnih pogledov je bil Carl Orff (1895-1982), ki je v svoj inovativni pristop k poučevanju glasbe vključeval gibanje ob glasbi, petje osnovnih melodičnih motivov in intervalov, igranje osnovnih ritmov in improvizacijo (Thresher, 1964).

Povezovanje gibanja in glasbe je lahko uporaben didaktičen pristop (Hallam, 2010). Razvijanje ritmičnih sposobnosti naj bi pripomoglo $\mathrm{k}$ boljšemu razumevanju in pomnjenju različnih gibanj. Izvajanje gibalnih spretnosti ob glasbi, ki je ritmično usklajena z gibanjem, pripomore $\mathrm{k}$ bolj natančni (Anshel in Marisi, 1978; Painter, 1966) in pravilni (Beisman, 1967) izvedbi teh spretnosti. Prav tako umeščanje gibanja v poučevanje glasbe izboljša ritmične sposobnosti (Zachopoulou, Derri, Chatzopoulos in Ellinoudis, 2003). Študije so pokazale, da je medpredmetno povezovanje gibanja in glasbe $\mathrm{v}$ predšolskem obdobju učinkovitejše za usvajanje lokomotornih spretnosti kot samo gibanje (Zachopoulou, Bakle in Deli, 2006; Derri, Tsapakidou, Zachopoulou in Kioumourtzoglou, 2001) in prosta igra (Brown, Sherrill in Gench, 1981; Deli, Bakle in Zachopoulou, 2006).

\section{Problem, namen in cilji raziskave}

Medtem ko študije $\mathrm{v}$ mednarodnem prostoru dokazujejo pozitivne učinke povezovanja gibanja in glasbe na usvajanje TGS $\mathrm{v}$ predšolskem obdobju, $\mathrm{v}$ slovenskem prostoru ne zasledimo podobne študije. Prav tako se študije učinkov povezovanja gibalnih in glasbenih vsebin omejujejo na ločeno preverjanje vplivov takšnega programa na usvajanje gibalnih spretnosti in razvoj ritmičnih sposobnosti. Zato smo se lotili raziskave, v okviru katere smo preverjali, kako povezovanje gibalnih in glasbenih dejavnosti $v$ predšolskem obdobju vpliva na usvajanje različnih 
TGS in razvoj ritmičnih sposobnosti. Pri tem nas je zanimalo, ali je gibalno-glasbeni program uspešnejši od gibalnega programa in javnega programa za predšolske otroke.

\section{Raziskovalna vprašanja}

Zastavili smo si naslednji raziskovalni vprašanji:

- Ali obstajajo razlike med začetnim in končnim stanjem otrok gibalno-glasbenega programa, gibalnega programa in javnega programa v TGS ter razvitosti ritmičnega posluha?

- Ali obstajajo razlike v napredku TGS in ritmičnega posluha med skupinami, $\mathrm{v}$ katerih se je izvajal gibalno-glasbeni program, gibalni program oz. javni program?

\section{Metodologija}

\section{Raziskovalna metoda}

Uporabili smo enofaktorsko eksperimentalno raziskovalno metodo s tremi modalitetami in skupinami otrok kot primerjalnimi skupinami.

\section{Raziskovalni vzorec}

Raziskovalni vzorec je bil neslučajnostni iz konkretne populacije predšolskih otrok, starih od 5 do 6 let $(M=5,6 ; S D=0,4) . Z$ namenom in vsebino raziskave je bilo predhodno seznanjeno vodstvo vrtca, ki je podalo soglasje $\mathrm{k}$ izvajanju zastavljenega programa in postopkom zbiranja podatkov. $\mathrm{V}$ raziskavo so bili vključeni samo otroci, katerih starši so podali soglasje k sodelovanju v raziskavi. Vključenih je bilo 62 otrok, od tega $53 \%(n=33)$ dečkov in $47 \%$ deklic $(n=29)$. Otroci so bili razdeljeni $\mathrm{v}$ dve eksperimentalni skupini in eno kontrolno skupino. V eksperimentalni skupini je bilo vključenih 35 otrok, od tega 18 otrok (29\%) v skupino gibalno-glasbenega programa (GGLP) in 17 otrok (27\%) v skupino gibalnega programa (GP). V kontrolno skupino, ki je izvajala usmerjene dejavnosti 
s področja gibanja in glasbe $\mathrm{v}$ skladu $\mathrm{z}$ javnim programom (JP) za predšolske otroke, je bilo vključenih 27 (44\%) otrok.

Postopki zbiranja podatkov

Temeline gibalne spretnosti

Podatke smo zbrali s kvantitativno tehniko, s standardiziranimi merskimi nalogami, primernimi za otroke, stare od 3 do 10 let (Okely, Booth in Chey, 2004). Vsaki lokomotorni (tek in sonožni vertikalni skok) in manipulativni (podaja žoge z obema rokama, odbijanje žoge na mestu, udarec žoge $z$ nogo in udarec žoge $z$ loparjem) gibalni spretnosti smo določili šest kazalcev, po katerih smo ocenjevali pravilno izvedbo gibanja. Za vsak pravilno izveden kazalec je otrok prejel točko, tako da je razpon ocene za posamezno gibalno spretnost znašal od 0 do 6 točk. Skupno oceno smo izračunali tako, da smo ocene posameznih gibalnih spretnosti sešteli. Otrok je lahko skupaj dosegel 36 točk, od tega za sklop lokomotornih spretnosti 12 točk in za sklop manipulativnih spretnosti 24 točk. Pred izvedbo posamezne gibalne spretnosti so otroci prejeli navodila $\mathrm{v}$ obliki razlage, vsaka spretnost pa je bila tudi demonstrirana.

Dva ocenjevalca, ki sta bila usposobljena za ocenjevanje gibalnih spretnosti, sta ocenila vsakega otroka. Aritmetično sredino obeh ocen smo uporabili za nadaljnjo statistično obdelavo. Ocene ocenjevalcev so pokazale visoko notranjo konsistentnost $\geq 0,70$ (Fayers in Machin, 2013) za vseh šest obravnavanih gibalnih spretnosti (Cronbach $\alpha=0,98$ ), prav tako tudi za sklop lokomotornih (Cronbach $\alpha$ $=0,93$ ) in manipulativnih spretnosti (Cronbach $\alpha=0,85$ ). Interklasni koeficient korelacije je pokazal visoko stopnjo zanesljivosti $\geq 0,80$ med ocenjevalcema za lokomotorne (ICC $=0,81-0,89)$ in manipulativne spretnosti (ICC $=0,80-0,87)$, prav tako tudi znotraj ocenjevalcev (lokomotorne ICC $=0,89$; manipulativne ICC $=$ $0,85)$.

\section{Ritmični poslub}

Podatke o stopnji razvitosti ritmičnega posluha smo zbrali z naslednjimi testi: 
a) Test za ugotavljanje enakih in razlicnih ritmicni vzorcev (Gordon, 1986)

Otroci ugotavljajo, ali sta dva ritmična vzorca enaka ali različna. Test rešujejo tako, da obkrožijo dva enaka obraza, če slišijo dva enaka ritmična vzorca, oz. dva različna obraza, če slišijo dva različna ritmična vzorca. Posamezna vprašanja so označena z risbami predmetov, ki so otrokom znani. Ritmični test je sestavljen iz petnajstih nalog in dveh poskusnih nalog. Vsaka pravilno rešena naloga se oceni z eno točko.

b) Test za posnemanje govorjenih ritmicnih fraz (Denac, 2002)

Test je izdelan za namene raziskovalne naloge in vsebuje naloge za posnemanje govorjenih ritmičnih fraz. Test sestavlja pet nalog za posnemanje govorjenih ritmičnih fraz in dve poskusni nalogi. Kriterij za ocenjevanje je stopnja pravilne ponovitve govorjenih ritmičnih fraz. $\mathrm{V}$ celoti pravilno rešena naloga je ocenjena s tremi točkami, delno pravilno rešena naloga $z$ dvema točkama in $\mathrm{v}$ celoti nepravilno rešena $z$ eno točko.

c) Test za prepoznavanje kratkih in dolgih tonov (Denac, 2002)

$\mathrm{Na}$ klavirju na tonu g1 zaigramo kratke in dolge tone. Dolžino trajanja otroci zapisujejo z ravno črto. Test vsebuje deset nalog. Vsaka pravilno rešena naloga je ocenjena $z$ eno točko.

č) Test za ugotavljanje tę̌kih in labkih dob (Denac, 2002)

$\mathrm{Na}$ boben izvajamo štiridobni takt s poudarjenimi in nepoudarjenimi dobami. Ko otrok zasliši poudarjeno dobo, na papir v kvadrat nariše piko. Izvajanje vključuje deset poudarjenih in deset nepoudarjenih dob. Vsaka pravilno rešena naloga se ovrednoti z eno točko.

d) Test za ugotavljanje skladnosti gibanja v ritmu skladbe Franz Schubert: Vojaška koračnica (Denac, 2002)

Otroci najprej samo prisluhnejo skladbi. Ob ponovnem poslušanju jih spodbudimo za gibalno izražanje doživetij in predstav glasbenega dela in opazujemo skladnost gibanja v ritmu glasbe. Skladno gibanje v celotni skladbi ocenimo s tremi točkami, skladno gibanje $\mathrm{v}$ delu skladbe ocenimo $\mathrm{z}$ dvema točkama, neskladno gibanje $\mathrm{v}$ celotni skladbi z eno točko. 


\section{Postopki obdelave podatkov}

Podatke smo kvantitativno obdelali z osnovno opisno statistiko, razliko med otroki, ki so sodelovali $\mathrm{v}$ gibalno-glasbenem programu, gibalnem programu in javnem programu, pa smo preverili z enofaktorsko analizo variance. $V$ nadaljevanju analize smo razlike med pari programov ugotavljali s pomočjo Bonferronijevega testa. Velikost učinka smo izračunali s pomočjo $\eta^{2}$, pri čemer smo učinek interpretirali: 0 $0,01=$ nepomemben učinek, $0,02-0,13=$ majhen učinek, $0,13-0,25=$ srednje velik učinek in $\geq 0.26$ = velik učinek (Cohen, 1988). Razlike med začetnim in končnim stanjem posamezne skupine smo preverili $\mathrm{s}$ t-preizkusom za odvisne vzorce. Velikost učinka smo izračunali s pomočjo Cohenovega d-indeksa, pri čemer smo učinek interpretirali: $0-0,1=$ nepomemben učinek, $0,2-0,4=$ majhen učinek, $0,5-$ $0,7=$ srednje velik učinek in $\geq 0.8=$ velik učinek (Cohen, 1992). Napredek smo izračunali kot razliko med ocenami končnega stanja in začetnega stanja (napredek [točke] $=$ končno stanje [točke] - začetno stanje[točke]).

\section{Eksperimentalni program}

Gibalno-glasbeni program (GGLP) je trajal pet tednov in vključeval 19 usmerjenih dejavnosti, katerih cilj je bil usvojiti izbrane gibalne spretnosti (tek, sonožni vertikalni skok, podaja žoge z obema rokama, odbijanje žoge na mestu, udarec žoge z nogo in udarec žoge $z$ loparjem) in doseči višjo stopnjo razvitosti ritmičnega posluha. Vsaka usmerjena dejavnost je bila sestavljena iz uvodnega dela, $v$ katerem so se otroci čustveno in telesno pripravili na glavni del, v katerem so izvajali različne naloge, ki so povezovale gibanje in glasbo, ter zaključnega dela, v katerem so se otroci umirili. $\mathrm{V}$ povprečju je trajala vsaka usmerjena dejavnost 40 minut. Nekaj primerov povezovanja gibanja in glasbe: reproduciranje enakih in različnih ritmičnih in melodičnih vzorcev (npr. enakomerno odbijanje žoge v danem ritmu, visoko/nizko odbijanje žoge glede na višino tona), posnemanje govorjenih ritmičnih fraz (npr. posnemanje govorjene ritmične fraze $z$ odbijanjem žoge s pomočjo loparja), prepoznavanje dolgih in kratkih tonov (npr. igra spreminjanja dolžine korakov pri teku v skladu z dolgimi/kratkimi toni, hiter odriv - doooolg skok), prepoznavanje lahkih in težkih dob (npr. stečem/lahke dobe in se močno odrinem/težka doba ob igranju na ksilofon), usklajevanje gibanja $\mathrm{z}$ ritmom glasbe (npr. uskladitev zaleta in udarca žoge z nogo z igranim ritmom na tamburin, razgibavanje ob glasbi). Večino 
dejavnosti smo izvedli v okviru glasbeno-didaktičnih iger z jasno zastavljenimi cilji, ki so temeljili na medpredmetnem povezovanju gibalnih in glasbenih dejavnosti.

Gibalni program (GP) je trajal pet tednov in zajemal 19 usmerjenih dejavnosti, katerih cilj je bil usvojiti izbrane gibalne spretnosti (tek, sonožni vertikalni skok, podaja žoge z obema rokama, odbijanje žoge na mestu, udarec žoge z nogo in udarec žoge z loparjem). Struktura in čas trajanja posamezne usmerjene dejavnosti sta bila enaka dejavnosti gibalno-glasbenega programa. Bistvena razlika med programoma je bila v tem, da se v okviru gibalnega programa pri izvajanju temeljnih gibalnih spretnosti ni uporabljala glasba. Večina didaktičnih iger je bila enaka tistim, ki smo jih uporabili v sklopu gibalno-glasbenega programa.

Eksperimentalna skupina je bila deležna gibalno-glasbenega in gibalnega programa, kontrolna skupina pa je v času eksperimenta izvajala usmerjene dejavnosti s področja gibanja in glasbe $\mathrm{v}$ skladu $\mathrm{z}$ javnim programom $(\mathrm{JP})$ za predšolske otroke. $\mathrm{V}$ tem času je izvedla pet vadbenih ur in pet glasbenih uric, ki se med seboj niso povezovale. Vadbene ure so zajemale premagovanje poligonov z različnimi naravnimi oblikami gibanja, glasbene urice pa izvajanje različnih glasbenih dejavnosti.

Dejavnosti GGLP, GP in JP so izvajale vzgojiteljice in pomočnice vzgojiteljic, ki tudi sicer vodijo delo v oddelku. S tem smo se želeli izogniti ustvarjanju umetnega okolja, v katerem se otroci morda ne bi počutili prijetno, kar bi lahko vplivalo na rezultate raziskave. Načrtovanje GGLP in GP smo opravili skupaj z vzgojiteljicami, tako da so bile $z$ načrtovanimi dejavnostmi dobro seznanjene, kar je omogočilo učinkovito izvajanje in evalvacijo teh dejavnosti.

\section{Rezultati in interpretacija}

Pred izvedbo eksperimenta smo analizirali začetno stanje oziroma stopnjo razvitosti TGS in ritmičnega posluha skupin GGLP, GP in JP. Analiza variance je potrdila, da $\mathrm{v}$ začetnem stanju med skupinami ni bilo statistično značilnih razlik v razvitosti ritmičnega posluha (vsi $p \geq 0,207$ ) in TGS (vsi $p \geq 0,206$ ), razen $v$ sonožnem vertikalnem skoku ( $F=6,881, p=0,002, \eta 2=0,19)$. Pri tem je skupina JP $(M=$ $4,74 ; S D=0,90)$ dosegla statistično značilno boljši rezultat (Bonfferonijev test $\alpha_{c}<$ $0,0167)$ kot skupina GGLP $(M=3,72 ; S D=1,02)$. 
Tabela 1: Razlika v izbranih TGS med začetnim in končnim stanjem JP.

\begin{tabular}{|c|c|c|c|c|c|c|}
\hline & & AS & $\mathrm{SO}$ & $\mathrm{t}$ & $\mathrm{p}(\mathrm{t})$ & d \\
\hline \multirow{2}{*}{ Udarec žoge z nogo } & $\mathrm{ZS}$ & 5,04 & 1,224 & 1,093 & 0,285 & $-0,24$ \\
\hline & $\mathrm{KS}$ & 4,74 & 1,228 & & & \\
\hline \multirow{2}{*}{ Tek } & ZS & 5,48 & 0,700 & $-1,000$ & 0,327 & 0,26 \\
\hline & $\mathrm{KS}$ & 5,67 & 0,734 & & & \\
\hline \multirow{2}{*}{ Sonožni vertikalni skok } & ZS & 4,74 & 0,903 & 0,205 & 0,839 & $-0,05$ \\
\hline & $\mathrm{KS}$ & 4,70 & 0,724 & & & \\
\hline \multirow{2}{*}{ Podaja žoge z obema rokama } & $\mathrm{ZS}$ & 4,26 & 1,228 & $-0,501$ & 0,621 & 0,14 \\
\hline & KS & 4,41 & 0,971 & & & \\
\hline \multirow{2}{*}{ Odbijanje žoge na mestu } & ZS & 3,96 & 1,091 & 0,000 & 1,000 & 0,00 \\
\hline & $\mathrm{KS}$ & 3,96 & 1,091 & & & \\
\hline \multirow{2}{*}{ Udarec žoge z loparjem } & $\mathrm{ZS}$ & 3,26 & 0,813 & $-1,664$ & 0,108 & 0,51 \\
\hline & $\mathrm{KS}$ & 3,74 & 1,059 & & 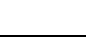 & \\
\hline
\end{tabular}

Ocene izbranih TGS JP so pokazale, da ni prišlo do statistično značilnih razlik med začetnim in končnim stanjem (vsi $p \geq 0,108)$. Največji učinek je JP imel na napredek otrok v udarcu žoge z loparjem $(\mathrm{d}=0,51)$ in najmanjšega oz. nikakršnega na odbijanje žoge na mestu $(\mathrm{d}=0,00)$ (tabela 1$)$.

Tabela 2: Razlika v stopnji razvitosti ritmičnega posluha med začetnim in končnim stanjem JP.

\begin{tabular}{lrrrrrc}
\hline & & AS & SO & t & p (t) & d \\
\hline Prepoznavanje enakih & in različnihZS & 8,22 & 2,259 & 0,442 & 0,662 & $-0,12$ \\
ritmičnih vzorcev & KS & 7,93 & 2,731 & & & \\
\hline \multirow{2}{*}{ Posnemanje govorjenih ritmičnih fraz } & ZS & 10,33 & 2,882 & $-2,327$ & $0,028^{*}$ & 0,45 \\
& KS & 11,52 & 2,424 & & & \\
\hline \multirow{2}{*}{ Prepoznavanje kratkih in dolgih tonov } & ZS & 3,37 & 2,677 & $-0,736$ & 0,468 & 0,11 \\
& KS & 3,67 & 2,660 & & & \\
\hline \multirow{2}{*}{ Prepoznavanje lahkih in težkih dob } & ZS & 3,22 & 1,396 & 0,250 & 0,805 & $-0,05$ \\
& KS & 3,15 & 1,512 & & & \\
\hline \multirow{2}{*}{ Skladnost gibanja v ritmu glasbe } & ZS & 2,41 & 0,572 & $-1,727$ & 0,096 & 0,34 \\
& KS & 2,59 & 0,501 & & & \\
\hline
\end{tabular}

Legenda: ZS - začetno stanje, $K S$ - končno stanje, $A S$ - aritmetična sredina, $S O$ - standardni odklon, $t$ - vrednost t-testa za odvisne vzorce, $p(t)$ - statisticna značilnost t-testa za odvisne vzorce, $d$-Cohenov $d,{ }^{*} p(t)<0,05$ 
V meritvah razvitosti ritmičnega posluha otrok JP je prišlo do statistično značilnih razlik med začetnim in končnim stanjem pri posnemanju govorjenih ritmičnih fraz $(\mathrm{t}=-2,33 ; p=0,028 ; \mathrm{d}=0,45)$ (tabela 2). Otroci JP so dosegli na končnem merjenju $(M=11,52 ; S D=2,42)$ za 1,19 točke boljši rezultat kot na začetnem merjenju $(M=$ $10,33 ; S D=2,88)$. Pri drugih nalogah ni prišlo do statistično značilnih razlik (vsi $p$ $\geq 0,096$ ), prav tako so bili učinki majhni oz. zanemarljivo majhni.

Tabela 3: Razlika v izbranih TGS med začetnim in končnim stanjem GP.

\begin{tabular}{llccccc}
\hline & & AS & SO & t & p (t) & d \\
\hline \multirow{2}{*}{ Udarec žoge z nogo } & ZS & 4,88 & 1,054 & 0,643 & 0,529 & $-0,15$ \\
& KS & 4,71 & 1,160 & & & \\
\hline \multirow{2}{*}{ Tek } & ZS & 4,94 & 1,298 & $-1,765$ & 0,097 & 0,71 \\
& KS & 5,65 & 0,702 & & & \\
\hline \multirow{2}{*}{ Sonožni vertikalni skok } & ZS & 4,47 & 0,800 & $-2,393$ & $0,029 *$ & 0,70 \\
& KS & 5,12 & 1,054 & & & \\
\hline \multirow{2}{*}{ Podaja žoge z obema rokama } & ZS & 4,29 & 0,849 & $-1,852$ & 0,083 & 0,51 \\
& KS & 4,82 & 1,237 & & & \\
\hline \multirow{2}{*}{ Odbijanje žoge na mestu } & ZS & 3,65 & 1,115 & $-4,070$ & $0,001 *$ & 1,11 \\
& KS & 4,88 & 1,111 & & & \\
\hline \multirow{2}{*}{ Udarec žoge z loparjem } & ZS & 3,47 & 1,179 & $-1,329$ & 0,203 & 0,33 \\
& KS & 3,88 & 1,269 & & & \\
\hline
\end{tabular}

Legenda: $Z S$ - začetno stanje, $K S$ - končno stanje, $A S$ - aritmetična sredina, SO - standardni odklon, $t$ - vrednost t-testa za odvisne vzorce, $p(t)$ - statistična značilnost t-testa za odvisne vzorce, $d$-Cohenov $d,{ }^{*} p(t)<0,05$

Ocene v izbranih TGS med začetnim in končnim stanjem skupine GP so pokazale statistično značilne razlike s srednje velikim učinkom $\mathrm{v}$ sonožnem vertikalnem skoku $(\mathrm{t}=-2,39 ; p=0,029 ; \mathrm{d}=0,70)$ in statistično značilne razlike $\mathrm{z}$ velikim učinkom $\mathrm{v}$ odbijanju žoge na mestu ( $\mathrm{t}=-4,07 ; p=0,001 ; \mathrm{d}=1,11)$ (tabela 3). Pri aktivnosti, kjer so otroci odbijali žogo na mestu, je bilo končno stanje $(M=4,88$; $S D=1,11)$ za 1,23 točke boljše od začetnega stanja $(M=3,65 ; S D=1,12)$, rezultat se je izboljšal za $34 \%$. Pri sonožnem vertikalnem skoku je bilo končno stanje $(M=5,12 ; S D=$ $1,05)$ za 0,65 točke boljše od začetnega stanja $(M=4,47 ; S D=0,80)$. Poleg sonožnega vertikalnega skoka so se pokazale razlike s srednje velikim učinkom GP še pri teku $(\mathrm{d}=0,71)$ in podajanju žoge $(\mathrm{d}=0,51)$. Pri udarcu žoge $\mathrm{z}$ loparjem $(\mathrm{d}=$ $0,33)$ so se pokazale razlike $z$ majhnim učinkom, pri udarcu žoge z nogo pa so bili učinki zanemarljivo majhni $(\mathrm{d}=-0,15)$. 
Tabela 4: Razlika v stopnji razvitosti ritmičnega posluha med začetnim in končnim stanjem GP.

\begin{tabular}{lcccccc}
\hline & & AS & SO & $\mathrm{t}$ & $\mathrm{p}(\mathrm{t})$ & $\mathrm{d}$ \\
\hline Prepoznavanje enakih in & $\mathrm{ZS}$ & 9,00 & 2,574 & 0,695 & 0,497 & 0,25 \\
različnih ritmičnih vzorcev & $\mathrm{KS}$ & 9,65 & 2,621 & & & \\
\hline Posnemanje govorjenih & $\mathrm{ZS}$ & 9,12 & 2,497 & $-3,125$ & $0,007^{*}$ & 0,57 \\
ritmičnih fraz & $\mathrm{KS}$ & 10,59 & 2,671 & & & \\
\hline Prepoznavanje kratkih in dolgih ZS & 4,18 & 3,187 & $-1,456$ & 0,165 & 0,24 \\
tonov & $\mathrm{KS}$ & 4,94 & 3,172 & & & \\
\hline Prepoznavanje lahkih in težkih & $\mathrm{ZS}$ & 2,76 & 1,678 & $-2,954$ & $0,009 *$ & 0,85 \\
dob & $\mathrm{KS}$ & 4,18 & 1,667 & & & \\
\hline \multirow{2}{*}{ Skladnost gibanja v ritmu glasbe } & $\mathrm{ZS}$ & 2,18 & 0,636 & $-2,063$ & 0,056 & 0,50 \\
& $\mathrm{KS}$ & 2,47 & 0,514 & & & \\
\hline
\end{tabular}

Legenda: ZS - začetno stanje, $K S$ - končno stanje, AS - aritmetična sredina, SO - standardni odklon, $t-v r e d n o s t$ $t$-testa za odvisne vzorce, $p(t)$ - statisticna značilnost t-testa za odvisne vzorce, $d$-Cohenov $d,{ }^{*} p(t)<0,05$

Meritve stopnje razvitosti ritmičnega posluha so pokazale statistično značilne razlike med začetnim in končnim stanjem skupine GP $\mathrm{z}$ velikim učinkom $\mathrm{v}$ prepoznavanju lahke in težke dobe $(\mathrm{t}=-2,95 ; p=0,009 ; \mathrm{d}=0,85)$ in s srednje velikim učinkom $\mathrm{v}$ posnemanju govorjenih ritmičnih fraz $(\mathrm{t}=-3,13 ; p=0,007 ; \mathrm{d}=0,57)$ (tabela 4). Otroci so bili v končnem stanju $(M=4,18 ; S D=1,67)$ za kar $51 \%$ točk boljši v prepoznavanju lahke in težke dobe kot v začetnem stanju $(M=2,76 ; S D=1,68)$. GP je vplival s srednje velikim učinkom še na skladnost gibanja $\mathrm{v}$ ritmu glasbe $(\mathrm{d}=$ $0,50)$, vendar brez statistično značilne razlike $(t=-2,06 ; p=0,056) . \mathrm{Na}$ prepoznavanje enakih in različnih ritmičnih vzorcev $(\mathrm{d}=0,25)$ in dolgih in kratkih zvokov $(\mathrm{d}=0,24)$, je imel GP majhen učinek. 
Tabela 5: Razlika v izbranih TGS med začetnim in končnim stanjem GGLP.

\begin{tabular}{|c|c|c|c|c|c|c|}
\hline & & AS & $\mathrm{SO}$ & $\mathrm{t}$ & $\mathrm{p}(\mathrm{t})$ & $\mathrm{d}$ \\
\hline \multirow{2}{*}{ Udarec žoge z nogo } & $\mathrm{ZS}$ & 4,39 & 1,290 & $-4,373$ & $0,000^{*}$ & 0,97 \\
\hline & KS & 5,39 & 0,778 & & & \\
\hline \multirow{2}{*}{ Tek } & $\mathrm{ZS}$ & 5,28 & 1,018 & $-1,844$ & 0,083 & 0,41 \\
\hline & KS & 5,61 & 0,608 & & & \\
\hline \multirow{2}{*}{ Sonožni vertikalni skok } & $\mathrm{ZS}$ & 3,72 & 1,018 & $-7,114$ & $0,000^{*}$ & 2,32 \\
\hline & KS & 5,50 & 0,514 & & & \\
\hline \multirow{2}{*}{ Podaja žoge z obema rokama } & $\mathrm{ZS}$ & 3,94 & 0,938 & $-6,101$ & $0,000^{*}$ & 1,67 \\
\hline & KS & 5,44 & 0,856 & & & \\
\hline \multirow{2}{*}{ Odbijanje žoge na mestu } & $\overline{Z S}$ & 3,72 & 1,127 & $-8,043$ & $0,000^{*}$ & 1,78 \\
\hline & KS & 5,33 & 0,686 & & & \\
\hline \multirow{2}{*}{ Udarec žoge z loparjem } & ZS & 3,56 & 1,294 & $-6,519$ & $0,000^{*}$ & 1,48 \\
\hline & KS & 5,22 & 0,943 & & & \\
\hline
\end{tabular}

Razlike v izbranih TGS med začetnim in končnim stanjem GGLP so pogoste in velike, saj obstajajo statistično značilne razlike skoraj pri vseh nalogah (tabela 5). GGLP je z velikim učinkom deloval na napredek $\mathrm{v}$ naslednjih TGS: sonožni vertikalni skok $(\mathrm{t}=-7,11 ; p=0,000 ; \mathrm{d}=2,32)$, odbijanje žoge na mestu $(\mathrm{t}=-8,04$; $p=0,000 ; \mathrm{d}=1,78)$, podaja žoge z obema rokama $(\mathrm{t}=-6,10 ; p=0,000 ; \mathrm{d}=1,67)$, udarec žoge $\mathrm{z}$ loparjem $(\mathrm{t}=-6,52 ; p=0,000 ; \mathrm{d}=1,48)$ in udarec žoge $\mathrm{z}$ nogo $(\mathrm{t}=$ $-4,37 ; p=0,000 ; \mathrm{d}=0,97)$. Na tek je gibalno-glasbeni program vplival $\mathrm{z}$ majhnim učinkom $(\mathrm{d}=0,41)$. Glede na rezultate lahko sklepamo, da so dejavnosti gibalnoglasbenega programa imele pozitiven vpliv na rezultat večine TGS, z izjemo teka. 
Tabela 6: Razlika v stopnji razvitosti ritmičnega posluha med začetnim in končnim stanjem GGLP.

\begin{tabular}{|c|c|c|c|c|c|}
\hline & AS & $\mathrm{SO}$ & $\mathrm{t}$ & $\mathrm{p}(\mathrm{t})$ & d \\
\hline Prepoznavanje enakih in različnihZS & 9,44 & 2,093 & $-1,528$ & 0,145 & 0,49 \\
\hline ritmičnih vzorcev & 10,61 & 2,725 & & & \\
\hline Posnemanje govorjenih ritmičnihZS & 10,44 & 2,526 & $-5,692$ & $0,000^{*}$ & 1,05 \\
\hline fraz & 12,89 & 2,139 & & & \\
\hline Prepoznavanje kratkih in dolgihZS & 3,83 & 3,222 & $-4,745$ & $0,000^{*}$ & 1,08 \\
\hline tonov & 7,06 & 2,733 & & & \\
\hline \multirow{2}{*}{ Prepoznavanje lahkih in težkih dob $\mathrm{KS}$} & 4,06 & 2,940 & $-1,228$ & 0,236 & 0,36 \\
\hline & 5,00 & 2,326 & & & \\
\hline \multirow{2}{*}{ Skladnost gibanja v ritmu glasbe } & 2,17 & 0,618 & $-5,333$ & $0,000^{*}$ & 1,53 \\
\hline & 2,89 & 0,323 & & & \\
\hline
\end{tabular}

Legenda: ZS - začetno stanje, $K S$ - končno stanje, AS - aritmetična sredina, SO - standardni odklon, $t-v r e d n o s t$ t-testa za odvisne vzorce, $p(t)$ - statistična značilnost t-testa za odvisne vaorce, $d$-Cohenov $d,{ }^{*} p(t)<0,05$

Glede na prikazane podatke lahko sklepamo, da so dejavnosti GGLP pozitivno vplivale na razvoj ritmičnega posluha (tabela 6). Medpredmetno povezovanje gibanja in glasbe se je pokazalo kot učinkovito pri skladnosti gibanja $\mathrm{v}$ ritmu glasbe $(\mathrm{t}=-$ $5,33 ; p=0,000 ; \mathrm{d}=1,53)$, prepoznavanju dolgih in kratkih tonov $(\mathrm{t}=-4,75 ; p=$ $0,000 ; \mathrm{d}=1,08)$ in posnemanju govorjenih ritmičnih fraz $(\mathrm{t}=-5,69 ; p=0,000 ; \mathrm{d}=$ 1,05). Srednje velik učinek se je pokazal pri prepoznavanju enakih in različnih ritmičnih vzorcih $(\mathrm{d}=0,49)$, majhen učinek pa pri prepoznavanju lahkih in težkih $\operatorname{dob}(d=0,36)$.

Tabela 7: Razlike v napredku v izbranih TGS med JP, GP in GGLP.

\begin{tabular}{|c|c|c|c|c|c|c|c|c|c|}
\hline & & \multirow[t]{2}{*}{$\mathrm{N}$} & \multirow[t]{2}{*}{ AS } & \multirow[t]{2}{*}{ SO } & \multicolumn{2}{|c|}{$\begin{array}{c}\text { Levenov preizkus } \\
\text { homogenosti varianc }\end{array}$} & \multicolumn{2}{|c|}{$\begin{array}{c}\text { Preizkus razlik } \\
\text { (ANOVA) }\end{array}$} & \multirow{2}{*}{$\eta^{2}$} \\
\hline & & & & & $\mathrm{F}$ & $\mathrm{p}(\mathrm{F})$ & $\mathrm{F}$ & $\mathrm{p}(\mathrm{F})$ & \\
\hline \multirow{3}{*}{ Udarec žoge z nogo } & JP & 27 & $-0,30$ & 1,409 & \multirow{3}{*}{1,105} & \multirow{3}{*}{0,338} & \multirow{3}{*}{6,734} & \multirow{3}{*}{$0,002^{*}$} & \multirow{3}{*}{0,19} \\
\hline & GP & 17 & $-0,18$ & 1,131 & & & & & \\
\hline & GGLP & 18 & 1,00 & 0,970 & & & & & \\
\hline \multirow{3}{*}{ Tek } & $\mathrm{JP}$ & 27 & 0,19 & 0,962 & \multirow{3}{*}{8,869} & \multirow{3}{*}{0,000} & \multirow{3}{*}{$\begin{array}{l}0,709 \\
\text { Welch }\end{array}$} & \multirow{3}{*}{$\begin{array}{r}0,499 \\
\text { Welch }\end{array}$} & \multirow{3}{*}{0,04} \\
\hline & GP & 17 & 0,71 & 1,649 & & & & & \\
\hline & GGLP & 18 & 0,33 & 0,767 & & & & & \\
\hline \multirow{4}{*}{$\begin{array}{l}\text { Sonožni vertikalni } \\
\text { skok }\end{array}$} & $\mathrm{JP}$ & 27 & $-0,04$ & 0,940 & \multirow{3}{*}{0,798} & \multirow{3}{*}{0,455} & \multirow{3}{*}{16,947} & \multirow{3}{*}{$0,000^{*}$} & \multirow{3}{*}{0,36} \\
\hline & GP & 17 & 0,65 & 1,115 & & & & & \\
\hline & GGLP & 18 & 1,78 & 1,060 & & & & & \\
\hline & JP & 27 & 0,15 & 1,537 & 1,289 & 0,283 & 5,791 & $0,005^{*}$ & 0,16 \\
\hline
\end{tabular}




\begin{tabular}{llllllllll}
\hline Podaja žoge z obema & GP & 17 & 0,53 & 1,179 & & & & & \\
rokama & GGLP & 18 & 1,50 & 1,043 & & & & & \\
\hline \multirow{2}{*}{$\begin{array}{l}\text { Odbijanje žoge na } \\
\text { mestu }\end{array}$} & JP & 27 & 0,00 & 1,494 & & & & \\
& GP & 17 & 1,24 & 1,251 & 1,675 & 0,196 & 10,007 & $0,000^{*}$ & 0,25 \\
& GGLP & 18 & 1,61 & 0,850 & & & & & \\
\hline \multirow{2}{*}{$\begin{array}{l}\text { Udarec žoge z } \\
\text { loparjem }\end{array}$} & JP & 27 & 0,48 & 1,503 & & & & & \\
& GP & 17 & 0,41 & 1,278 & 0,951 & 0,392 & 5,294 & $0,008^{*}$ & 0,15 \\
& GGLP & 18 & 1,67 & 1,085 & & & & & \\
\hline
\end{tabular}

Legenda: $N$ - stevilo merjencev, $A S$ - aritmeticna sredina, $S O$ - standardni odklon, ANOVA - enofaktorska analiza varianc, Welch - Welchev F-preizkus, $\eta^{2}-$ eta na kevadrat, * $p(t)<0,05$

Izidi analize variance so pokazali, da obstajajo statistično značilne razlike $\mathrm{v}$ napredku med JP, GP in GGLP $z$ velikim učinkom glede na učni program v sonožnem vertikalnem skoku ( $F=16,947, p=0,000, \eta 2=0,36$ ) (tabela 7). Delno lahko nastalo razliko pripišemo tudi razliki $\mathrm{v}$ začetnem stanju, $\mathrm{v}$ katerem je skupina JP dosegla statistično značilno boljši rezultat kot skupina GGLP. Otroci v zgodnjih fazah psihomotoričnega učenja namreč praviloma dosegajo večje napredke $\mathrm{v}$ procesu učenja kot tisti v kasnejših fazah. Seveda pa lahko pri tako velikih razlikah v aritmetičnih sredinah (JP $=-0,04$; GGLP $=1,78)$ večji del napredka vendarle pripišemo programu vadenja. Srednje velik učinek glede na učni program $s$ statistično značilnimi razlikami med skupinami se je pokazal pri odbijanju žoge na mestu $(F=10,007, p=0,000, \eta 2=0,25)$, udarcu žoge z nogo $(F=6,73, p=0,002$, $\eta 2=0,19)$, podaji žoge z obema rokama $(\mathrm{F}=5,791, p=0,005, \eta 2=0,16)$ in udarcu žoge z loparjem ( $F=5,294, p=0,008, \eta 2=0,15)$. Pri vseh omenjenih TGS lahko razberemo tendenco $v$ napredku JP $<$ GP $<$ GGLP (udarec žoge z nogo, sonožni vertikalni skok, podaja žoge z obema rokama, odbijanje žoge na mestu) oz. GP < JP $<$ GGLP (udarec žoge z loparjem), ki kaže, da je GGLP doprinesel k največjemu napredku.

Majhen učinek glede na program brez statistično značilnih razlik med skupinami se je pokazal pri teku $(F=0,709, p=0,499, \eta 2=0,04)$. Razberemo lahko tendenco $\mathrm{v}$ napredku JP < GGLP < GP, ki kaže, da je GP doprinesel k največjemu napredku v teku. Nadaljnja analiza s pomočjo Bonfferonijevega popravka $\left(\alpha_{c}<0,0167\right)$ je pokazala, da sta bila GP in GGLP statistično značilno uspešnejša od JP v podaji žoge z obema rokama in odbijanju žoge na mestu. GGLP je bil statistično značilno uspešnejši od JP in GL v udarcu žoge z nogo, sonožnem vertikalnem skoku in udarcu žoge $\mathrm{z}$ loparjem. 
Tabela 8: Razlike v stopnji razvitosti ritmičnega posluha JP, GP in GGLP.

\begin{tabular}{|c|c|c|c|c|c|c|c|c|}
\hline & \multirow[t]{2}{*}{$\mathrm{N}$} & \multirow[t]{2}{*}{ AS } & \multirow[t]{2}{*}{$\mathrm{SO}$} & \multicolumn{2}{|c|}{$\begin{array}{l}\text { Levenov preizkus } \\
\text { homogenosti } \\
\text { varianc }\end{array}$} & \multicolumn{2}{|c|}{$\begin{array}{l}\text { Preizkus razlik } \\
\text { (ANOVA) }\end{array}$} & \multirow[t]{2}{*}{$\eta^{2}$} \\
\hline & & & & $\mathrm{F}$ & $\mathrm{p}(\mathrm{F})$ & $\mathrm{F}$ & $\mathrm{p}(\mathrm{F})$ & \\
\hline 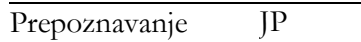 & 27 & $-0,30$ & 3,484 & \multirow{3}{*}{0,223} & \multirow{3}{*}{0,801} & \multirow{3}{*}{0,998} & \multirow{3}{*}{0,375} & \multirow{3}{*}{0,03} \\
\hline $\begin{array}{l}\text { Prepoznavanje } \\
\text { enakih in različnihGP }\end{array}$ & 17 & 0,65 & 3,840 & & & & & \\
\hline ritmičnih vzorcev GGLP & 18 & 1,17 & 3,240 & & & & & \\
\hline Posnemanje & 27 & 1,19 & 2,646 & \multirow{3}{*}{2,774} & \multirow{3}{*}{0,071} & \multirow{3}{*}{1,749} & \multirow{3}{*}{0,183} & \multirow{3}{*}{0,06} \\
\hline govorjenih ritmičnihGP & 17 & 1,47 & 1,940 & & & & & \\
\hline fraz GGLP & 18 & 2,44 & 1,822 & & & & & \\
\hline \multirow{2}{*}{$\begin{array}{l}\text { Prepoznavanje JP } \\
\text { kratkih in dolgihGP }\end{array}$} & 27 & 0,30 & 2,091 & \multirow{3}{*}{1,929} & \multirow{3}{*}{0,154} & \multirow{3}{*}{8,814} & \multirow{3}{*}{$0,000^{*}$} & \multirow{3}{*}{0,23} \\
\hline & 17 & 0,76 & 2,166 & & & & & \\
\hline tonov $\quad$ GGLP & 18 & 3,22 & 2,881 & & & & & \\
\hline \multirow{3}{*}{$\begin{array}{l}\text { Prepoznavanje } \\
\text { lahkih in težkih dob }\end{array}$} & 27 & $-0,07$ & 1,542 & \multirow{3}{*}{5,452} & \multirow{3}{*}{0,007} & \multirow{3}{*}{$\begin{array}{r}3,686 \\
\text { Welch }\end{array}$} & \multirow{3}{*}{$\begin{array}{l}0,037 * \\
\text { Welch }\end{array}$} & \multirow{3}{*}{0,08} \\
\hline & 17 & 1,41 & 1,970 & & & & & \\
\hline & 18 & 0,94 & 3,262 & & & & & \\
\hline \multirow{3}{*}{$\begin{array}{l}\text { Skladnost gibanja v } \\
\text { ritmu glasbe }\end{array}$} & 27 & 0,19 & 0,557 & \multirow{3}{*}{0,350} & \multirow{3}{*}{0,706} & \multirow{3}{*}{4,995} & \multirow{3}{*}{$0,010^{*}$} & \multirow{3}{*}{0,14} \\
\hline & 17 & 0,29 & 0,588 & & & & & \\
\hline & 18 & 0,72 & 0,575 & & & & & \\
\hline
\end{tabular}

Legenda: $N$ - stevilo merjencev, $A S$ - aritmetična sredina, SO - standardni odklon, ANOVA - enofaktorska analiza varianc, Welch - Welchev F-preizkeus, $\eta^{2}$ - eta na kvadrat, ${ }^{*} p(t)<0,05$

Analiza variance je pokazala, da obstajajo statistično značilne razlike v napredku med JP, GP in GGLP s srednje velikim učinkom glede na učni program v prepoznavanju dolgih in kratkih tonov $(\mathrm{F}=8,814, p=0,000, \eta 2=0,23)$ in skladnosti gibanja $\mathrm{v}$ ritmu glasbe $(\mathrm{F}=4,995, p=0,010, \eta 2=0,14)$ ter $\mathrm{z}$ majhnim učinkom $\mathrm{v}$ prepoznavanju lahke in težke dobe $(\mathrm{F}=3,686, p=0,037, \eta 2=0,08)$. Kljub temu da analiza variance ni pokazala statistično značilne razlike med programi, pa smo ugotovili majhen učinek učnih programov še pri posnemanju govorjenih ritmičnih fraz $\left(F=1,749, p=0,183, \eta^{2}=0,06\right)$ ter pri prepoznavanju enakih in različnih ritmičnih vzorcev $(\mathrm{F}=0,998, p=0,375, \eta 2=0,03)$.

Pri večini merskih postopkov preverjanja razvitosti ritmičnega posluha lahko razberemo tendenco v napredku JP < GP < GGLP, ki kaže, da je GGLP vplival na stopnjo razvitosti ritmičnega posluha pri predšolskih otrocih. GP se je izkazal kot najuspešnejši pri prepoznavanju lahkih in težkih dob, medtem ko je JP pričakovano najmanj vplival oz. zanemarljivo malo vplival na napredek $\mathrm{v}$ razvoju ritmičnega 
posluha. Glede na Bonfferonijev test $\left(\alpha_{c}<0,0167\right)$ smo ugotovili, da je GGLP statistično značilno uspešnejši od GP in JP pri skladnosti gibanja $v$ ritmu glasbe in prepoznavanju dolgih in kratkih zvokov.

\section{Sklep}

Izsledki raziskave kažejo, da povezovanje področja gibanja in glasbe pozitivno vpliva na učenje TGS in na razvoj ritmičnega posluha. $S$ pomočjo usmerjenih dejavnosti, $v$ katerih se prepletajo gibalne in glasbene vsebine, lahko otroci $\mathrm{v}$ enakem času in z enakim številom dejavnosti bolje usvojijo TGS kot otroci, ki vadijo TGS brez vključevanja glasbe. Enak učinek povezovanja gibanja in glasbe sta potrdili raziskavi Zachopoulou, Bakle in Deli (2006) in Derri, Tsapakidou, Zachopoulou in Kioumourtzoglou (2001).

Predvidevamo, da glasba spodbuja celostno učenje brez pretiranega osredotočanja na posamezne dele TGS, to pa ima za posledico bolj koordinirano in natančnejšo izvedbo gibanja. Predvsem v zgodnjem otroštvu je znano, da analitično odpravljanje napak pri izvedbi gibalnih spretnosti lahko privede do rušenja zaporedja gibalnih akcij, značilnih za posamezno spretnost (Marinšek in Rajtmajer, 2017). Z osredotočanjem na posamezno napako lahko onemogoči pravilno izvedbo drugih vidikov spretnosti, to pa opazimo kot neskladno oz. nepravilno izvedeno gibanje. $\mathrm{Na}$ podlagi rezultatov naše raziskave lahko sklepamo, da ob spremljavi glasbe otrok dojame gibalno spretnost bolj celostno kot brez njene spremljave. Glasba $-\mathrm{s}$ pomočjo aktivacije različnih vidikov ritmičnih sposobnosti - v tem primeru nastopi kot sredstvo spoznavnega procesa gibanja. Ob uporabi glasbe pri učenju gibanja se otroci odzivajo s telesom in razumom na tisto, kar slišijo oz. čutijo, zato lahko takšno učenje opredelimo kot celostni spoznavni proces.

Ugotovili smo tudi, da povezovanje gibanja in glasbe ugodno vpliva na razvoj ritmičnega posluha, še posebej se to kaže v sposobnosti skladnega gibanja v ritmu glasbe in prepoznavanju trajanja tonov. Takšen didaktični pristop ne ustvarja samo miselne predstave o ritmu, ampak v omenjene predstave vključuje tudi gibalni aparat, ki otroku veliko bolj celostno in plastično osmisli ritmični vidik glasbe. Očitno večje število različnih senzornih kanalov, ki jih preko miselnih procesov in telesne aktivnosti vključujemo $\mathrm{v}$ poučevanje glasbe, spodbuja razvoj ritmičnega posluha. Prav na interakcijskem odnosu procesov spoznavnega, čustvenega in gibalnega polja 
pa temelji glasbeni razvoj otroka. Kot nekoliko manj uspešno se je izkazalo povezovanje gibanja in glasbe $\mathrm{v}$ prepoznavanju oziroma doživljanju poudarjenih in nepoudarjenih dob, to pa lahko pripišemo manjšemu obsegu glasbeno-gibalnih dejavnosti $\mathrm{v}$ povezavi z občutenjem metruma.

Pomembno se nam zdi izpostaviti, da so tudi otroci GP dosegli višjo stopnjo v razvoju ritmičnega posluha $\mathrm{v}$ primerjavi $\mathrm{z}$ otroki JP. To potrjuje vpliv posameznih področij dejavnosti na celostni razvoj otrokove osebnosti oziroma na različne vidike otrokovega razvoja in učenja. Izsledki raziskave potrjujejo, da medpredmetno povezovanje velja za učinkovit didaktični pristop, ki otroka spodbuja k osmišljanju vsebin, omogoča trdnejše povezave med informacijami in s tem pripomore $\mathrm{k}$ trajnejšemu in bolj uporabnemu znanju.

\section{Summary}

Interdisciplinary teaching connects the common characteristics of various learning areas into a meaningful whole. Interdisciplinarity is promoted by the Kindergarten Curriculum within the principle of horizontal alignment, which points out that the linking of activities from various fields is justified and made useful by the interdependent nature of developmental aspects of children (Kurikulum za vrtce, 1999).

Existing studies of the effects of linking movement and musical content are limited to the examination of influences of such programmes on either motor skills or the development of rhythmic abilities separately. Therefore, we undertook a study into how the linking of motor and music activities in the pre-school period influences the acquisition of fundamental movement skills (FMS) and the development of rhythmic abilities (RA).

Sixty-two children aged from five to six years participated in the study and were divided into a movement group (MG; $\mathrm{n}=17)$, a music and movement group (MMG; $\mathrm{n}=18$ ), and a control group (CG; $\mathrm{n}=35)$. The MG participated in a five-week movement programme; the MMG participated in a five-week music and movement programme, and the CG was engaged in a standard five-week programme according to the Curriculum for kindergarten (1999). 
The FMS and the RA were assessed before and after the implementation of the intervention programme. The Test of Gross Motor Development - Second Edition (TGMD-2) was used for qualitative assessment of six FMS (Ulrich, 2000). We identified the level of development of rhythmic abilities with the following tests: same and different rbythmic pattern identification; repetition of spoken rbythmical phrases; identification of long and short tones; stressed and unstressed beat identification; and coherence of movement with the rhythm of a composition (Gordon, 1986; Denac; 2002, 2012a).

The research findings showed that linking movement and music had positive effects on FMS learning and the development of RA. With guided activities combining content from the fields of movement and music, children were able to apprehend FMS better than children who practiced FMS without music within the same period of time and with an equal number of activities. The same effect of linking movement and music had previously been confirmed in studies by Zachopoulou, Bakle and Deli (2006) and Derri, Tsapakidou, Zachopoulou and Kioumourtzoglou (2001).

We assume that music stimulates holistic learning without excessive focus on individual parts of FMS, resulting in a better coordinated and more accurate execution of movement. It is known that, particularly in early childhood, an analytical approach to correcting mistakes in the execution of motor skills can lead to disruption of the sequence of motor actions typical of an individual skill (Marinšek and Rajtmajer, 2017). Focusing on an individual mistake can prevent correct execution of other elements of the skill, which can be observed as a poorly coordinated or incorrect movement. Music can help a child to apprehend a motor skill more holistically, without getting entangled in the details. Music activates various aspects of rhythmic abilities, thus acting as a means for psychomotor learning. When music is used in the learning process, children react to what they hear or feel with their minds and bodies; therefore, such learning can be defined as a holistic cognitive process.

We also observed that linking movement and music had positive effects on the development of RA, which was reflected particularly in the ability to move coherently along with the rhythm of the music and in tone duration identification. Such a teaching approach not only creates cognitive conceptions of rhythm, but also includes the locomotor apparatus in those conceptions, which gives a child a much more holistic and plastic representation of the rhythmic aspect of music. It seems 
that involving a higher number of sensory channels in music teaching through cognitive processes and physical activity results in better learning results. The linking of movement and music was somewhat less successful with regard to identification of stressed and unstressed beats, which can be attributed to a smaller number of motor activities related to meter.

These research findings confirmed interdisciplinary teaching as an efficient teaching approach that encourages children to put the content into context, while enabling stronger connections among items of information, thus contributing to the creation of more durable and useful knowledge.

\section{Refernces}

Anshel, M., in Marisi, D. (1978). Effect of music and rhythm on physical performance, Research Quarterly, 49(2), 109-113.

Bachmann, M. L. (1995). Dalcroze Today: An Education through and into Music. Oxford: Oxford University Press.

Barnett, L. M., Van Beurden, E., Morgan, P. J., Brooks, L. O., in Beard, J. R. (2008). Does childhood motor skill proficiency predict adolescent fitness? Medicine and Science in Sports and Exercise, 40(12), 2137-2144.

Beisman, G. (1967). Effect of rhythmic accompaniment upon learning of fundamental motor skills. Research Quarterly, 38(2), 172-176.

Beurden, E., Zask, A., Barnett, L., in Dietrich, U. (2002) Fundamental movement skills - How do primary school children perform? The "Move it Groove it" program in rural Australia. Journal of Science \& Medicine in Sport, 5(3), 244-252.

Borota, B., in Kovačič Divjak, A. (2015). Dejavnosti glasbenega opismenjevanja. Koper: Univerzitetna založba Annales.

Božič, A., Habe, K., in Jerman, J. (2007). Povezanost glasbenih sposobnosti in fonološkega zavedanja pri predšolskih otrocih (raziskevalno poročilo). Postojna: Društvo psihologov Slovenije.

Brown, J., Sherrill, C., in Gench, B. (1981). Effects on an integrated physical education/music programme in changing early childhood perceptual-motor performance. Perceptual and Motor Skills, 53(1), 151-154.

Clarke, J. E. (2007). On the problem of motor skill development. Journal of Physical Education, Recreation and Dance, 78(5), 39-44.

Cohen, J. (1988). Statistical Power Analysis for the Behavioral Sciences (2nd edition). Hillsdale, NJ: Erlbaum.

Cohen, J. (1992). A power primer. Psychological Bulletin, 112(1), 155-159.

Dalcroze, J. E. (1932). Rhythmics and Pianoforte Improvisation. Music and Letters, 13(4), 371-380.

Denac, O. (2002). Glasba pri celostnem razvoju otrokove osebnosti. Ljubljana: Zavod Republike Slovenije za šolstvo.

Denac, O. (2012a). Načrtovanje glasbenib dejavnosti v zgodnjem obdobju otroštva. Maribor: Pedagoška fakulteta.

Denac, O. (2012b). Glasbene preference vzgojiteljev in predšolskih otrok. Revija za elementarno izobraževanje, 5(4), 29-38.

Denac, O., Čagran, B., Žnidaršič, J., in Sicherl-Kafol, B. (2013). Students' attitudes towards arts and cultural learning in the Slovenian educational system. Hrvatski časopis za odgoj $i$ obrazovanje, 15(3), 39-72. 
Derri, V., Tsapakidou, A., Zachopoulou E., in Kioumourtzoglou, E. (2001). Effect of a Music and Movement Programme on Development of Locomotor Skills by Children 4 to 6 Years of Age. European Journal of Physical Education, 6(1), 16-25.

Fayers, P., in Machin, D. (2013). Quality of Life: The assessment, analysis and interpretation of patient-reported outcomes. Chichester, England: John Wiley \& Sons.

Gallahue, D. L., in Ozmun, J. C. (2006). Understanding Motor Development (sixth edition). New York: The McGraw-Hill Companies.

Gašparović, M., Petrić, V., Stemberger, V., Rakovac, M., in Blažević, I. (2017). Kardiorespiratorna sposobnost učencev osnovnošolskega izobraževanja: povezava z antropometričnimi značilnostmi. Revija za elementarno izobraževanje, 10(4), 417-425.

Goodway, J. D., Robinson, L., in Crowe, H. (2013). Gender Differences in Fundamental Motor Skill Development in Disadvantaged Preschoolers From Two Geographical Regions. Research Quarterly for Exercise and Sport, 81(1), 17-24.

Gordon, E. (1986). Musikalische Begabung. Mainz: Schott.

Hallam, S. (2010). The power of music: Its impact on the intellectual, social and personal development of children and young people. International Journal of Music Education, 28(3), 269-289.

Hardy, L. L., King, L., Farrell, L., Macniven, R. in Howlett, S. (2009). Fundamental movement skills among Australian preschool children. Journal of Science and Medicine in Sport, 13(5), 503-508.

Jaakkola, T., Yli - Piipari, S., Huotari, P., Watt, A., in Liukkonen, J. (2016). Fundamental movement skills and physical fitness as predictors of physical activity: A 6-year follow-up study. Scandinavian Journal of Medicine \& Science in Sports, 26(1), 74-81.

Kurikulum za vrtce. (1999). Ljubljana: Ministrstvo za šolstvo in šport, Zavod RS za šolstvo.

Lemos, G. A., Avigo, E. L., in Barela, J. A. (2012). Physical education in kindergarten promotes fundamental movement skills. Advances in Physical Education, 2, 17-21.

Marinšek, M., in Rajtmajer, D. (2017). Fenomen psihomotoričnega učenja. V M. Marinšek in D. Rajtmajer (Ur.). Sport v funk ciji do ̌̌viljajske vagoje (str. 51-74). Ljubljana: Amalietti \& Amalietti.

Moog. H. (1968). Das Musikerleben des vorschulpflichtigen Kindes. Mainz: Schott.

Morrow, J. R., Tucker, J. S., Jackson, A. W., Martin, S. B., Greenleaf, C. A., in Petrie, T. A. (2013). Meeting physical activity guidelines and health-related fitness in youth. American Journal of Preventive Medicine, 44(5), 439-444.

Okely, A. D., Booth, M. L., in Chey, T. (2004). Relationships between body composition and fundamental movement skills among children and adolescents. Research Quarterly for Exercise and Sport, 75(3), 238-247.

Painter, G. (1966). The effects of a rhythmic and sensory motor activity program on perceptual motor spatial abilities of kindergarten children. Exceptional Children, 33(2), 113-116.

Pavlič Škerjanc, K. (2008). Integrativni kurikul ali kako povezati razdrobljeno. V M. Turk Škraba (ur.), Fleksibilni predmetnik - pot do ver̆je avtonomije, strokovne odgovornosti in kakovosti vagojnoižobraževalnega dela (str. 176-182). Ljubljana: Zavod Republike Slovenije za šolstvo.

Petrić, V., Kostadin, L., in Peić, M. (2018). Evaluation of an integrated programme of physical exercise with nursery-aged children: impact on motor achievements. Revija za elementarno izobraževanje, 11(3), 189-200.

Phillips - Silver, J., in Trainor, J. L. (2005). Feeling the Beat: Movement Influences Infant Rhythm Perception. Science, 308(5), 1430.

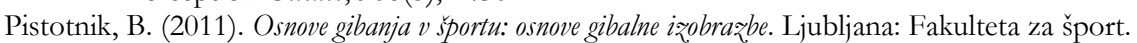

Pišot, R. (2012). Lifelong competency: model of motor development. Kinesiologia Slovenica, 18(3), 3546.

Rajtmajer, D. (2011). Nonlinearity in Sports Didactics. Physical Culture, 65(2), 86-91.

Sicherl - Kafol, B. (2007). Procesni in vsebinski vidiki medpredmetnega povezovanja. V J. Krek idr. (ur.), Učitelj v vlogi raziskovalca - Akcijsko rąiskovanje na področjih medpredmetnega povezovanja in vagojne zasnove v javni šoli (str. 112-130). Ljubljana: Pedagoška fakulteta Univerze v Ljubljani.

Seefeldt, V. (1980). Developmental motor patterns: Implications for elementary school physical education. Psychology of Motor Behavior and Sport, 36(6), 314-323. 
Sloboda, J. A. (1986). The Music Mind - The Cognitive Psychology of Music. Oxford: Clarendon Press.

Stodden, D. F., Goodway, J. D., Langendorfer, S. J., Roberton, M. A., Rudisill, M. E., Garcia, C. in Garcia, L. E. (2008). A developmental perspective on the role of motor skill competence in physical activity: An emergent relationship. Quest, 60, 290-306.

Stratton, G., McWhannell, N., Foweather, L., Henaghan, J., Graves, L., Ridgers, N. D. in Hepples, J. (2009). The A-CLASS project research findings: Summary Report. Liverpool, UK: Sportslinx.

Sušić, B. B. (2017). Music Education for Every Child-Ideal or Reality? Revija za elementarno iz̧obraževanje, 10(1), 85-97.

Thresher, J. M. (1964). The contributions of Carl Orff to elementary music education. Music Educators Journal, 50(3), 43-48.

Varl, K. K., in Duh, M. (2017). Prikaz medpredmetnega povezovanja na primeru implementacije sodobne umetnosti v osmi razred osnovne šole. Revija za elementarno izobraževanje, 10 (4), 377 397.

Zachopoulou, E., Bakle, I., in Deli, E. (2006). Implementing intervention movement programs for kindergarten children. Journal of Early Childhood Research, 4(1), 5-18.

Zachopoulou, E., Derri, V., Chatzopoulos, D., in Ellinoudis, T. (2003). Application of Orff and Dalcroze activities in preschool children: Do they affect the level of rhythmic ability? Physical Educator, 60(2), 50-56.

Zoglowek, H. G., in Aleksandrovich, M. (2016). Development through Movement-Psycho-pedagogical Analysis and Psychomotor Approaches. Revija za elementarno izobraževanje, 9(1-2), 151-172.

\section{Avtorji:}

\section{Dr. Miha Marinšek}

Associate professor, University of Maribor, Faculty of Education, Koroška cesta 160, 2000 Maribor Slovenia, e-mail: miha.marinsek@um.si

Izredni profesor, Univerza v Mariboru, Pedagoška fakulteta, Koroška cesta 160, 2000 Maribor, Slovenija, e-pošta: miha.marinsek@um.si

\section{Manja Šumer}

Master in early childhood education and care, Primary School Prežihovega Voranca Maribor, Gosposvetska 10, 2000 Maribor, Slovenia, e-mail: manja.sumer@gmail.com

Mag. prof. zgodnjega učenja in poučevanja, OŠ Prežihovega Voranca, Gosposvetska 10, 2000 Maribor, Slovenija, e-pošta: manja.sumer@gmail.com

\section{Dr. Olga Denac}

Full professor, University of Maribor, Faculty of Education, Koroška cesta 160, 2000 Maribor

Slovenia, e-mail: olga.denac@um.si

Redna profesorica, Univerza v Mariboru, Pedagoška fakulteta, Koroška cesta 160, 2000 Maribor,

Slovenija, e-pošta: olga.denac@um.si 
